\title{
Laboratory techniques in the diagnosis of herpes simplex infection
}

\author{
Rhoda L Ashley
}

A. Introduction

B. Clinical manifestations of genital herpes

1. Primary genital herpes

2. Non-primary first episodes

3. First episode reactivation

4. Recurrent genital herpes

5. Genital herpes in immunocompromised patients

6. Asymptomatic or unrecognised genital herpes

7. Genital herpes in pregnancy

8. Diagnostic testing of neonates

C. Laboratory techniques to detect HSV

1. Viral culture

a. Culture confirmation

b. HSV typing

c. Modified culture techniques

2. HSV direct detection tests
a. Cytology
b. Electron microscopy
c. HSV antigen detection
d. HSV DNA detection
e. HSV PCR

D. Serological techniques to detect $\mathrm{HSV}$ antibodies

1. General considerations

2. Functional antibody assays

a. Neutralising antibody assays $(\mathrm{Nt})$

b. Complement fixation (CF)

c. Antibody dependent cell cytotoxicity (ADCC)

3. Solid phase binding assays

a. Reverse passive hemagglutination (RPHA)

b Indirect fluorescent antibody assays (IFA)

c Enzyme immunoassays (EIA)

d Antibody typing by IFA or EIA

4. Type-specific immunoassays

a Protein-specific immunoassays

b Western blot ("immunoblot")

E. Future direction for HSV laboratory diagnosis

\section{Introduction}

Despite increased awareness of herpes simplex virus type 1 (HSV-1) and type 2 (HSV2) as sexually transmitted pathogens, genital herpes infections are underdiagnosed. The first indication of infection for many people is the transmission of the virus to a partner ${ }^{1-3}$ or, less frequently, to a neonate. ${ }^{4}$ In over half of horizontal transmission events and in over $70 \%$ of vertical transmission events, the source contact is unaware of being infected. The clinician must determine when and how to seek a diagnosis of genital herpes in the asymptomatic patient and must be able to recognise unusual as well as the more classical manifestations of genital HSV infections in order to arrive at appropriate counselling and treatment decisions. ${ }^{5-7}$ The virology laboratory can play a key role in these efforts.

The best laboratory test for most circumstances is viral culture; the growth and identification of $\mathrm{HSV}$ in permissive cells (table 1). Detection of $\mathrm{HSV}$ antigen or DNA after 16-48 hours in cell culture ("modified" or "shell vial" culture) offers rapid results which, in some formats, are comparable in sensitivity to standard culture. Tests to detect HSV antigen or DNA in the specimen itself ("HSV direct detection") require far less time to perform and can be as sensitive as culture techniques for symptomatic patients (table 1). "HSV-PCR", which uses polymerase chain reaction (PCR) to amplify HSV DNA in the sample is extremely sensitive and is the test of choice for diagnosing herpes encephalitis from cerebrospinal fluid (CSF). Other methods such as visualisation of the virus in patient specimens by electron microscopy and detection of infected cells by cytology or histology provide rapid diagnosis but lack the sensitivity of culture methods and the specificity of direct antigen or DNA detection tests.

Detection of antibodies to HSV is commonly used to diagnose genital herpes. Serologies may be of value in selected patients, particularly to document seroconversion to $\mathrm{HSV}$. However, current serologic methods have important limitations. Until commercial suppliers incorporate recent advances in HSV serological testing into their products, accurate serologies for a broad range of diagnostic circumstances will have limited availability.

Knowledge of the natural history of genital herpes can be useful for the laboratory manager in selecting which among diagnostic HSV tests to offer, and to the clinician for optimal use of the laboratory. Several aspects of genital HSV infections will be reviewed so that laboratory test descriptions can be made within the context of clinical application and interpretation.

Clinical manifestations of genital herpes

Primary genital herpes. While most genital herpes cases are caused by HSV- $2,{ }^{8} \mathrm{HSV}-1$ is the aetiological agent of $20-40 \%$ of first episodes of genital herpes. ${ }^{89}$ In the patient not previously infected with $\mathrm{HSV}$ of either type ("primary" genital herpes), HSV-1 and

\author{
Address correspondence to: \\ Children's Hospital and \\ Medical Center; CH-82 \\ 4800 Sand Point Way, N.E. \\ Seattle, WA 98105, USA \\ Laboratory Medicine, \\ Washington, Seattle, \\ WA 98195, USA \\ Rhoda L Ashley
}


Table 1 HSV detection methods

\begin{tabular}{|c|c|c|c|c|}
\hline Method & Appropriate Use & Specimens & Limitations & Time Required \\
\hline $\begin{array}{l}\text { Culture } \\
\text { Standard } \\
\text { viral culture }\end{array}$ & $\begin{array}{l}\text { Typical or atypical lesions } \\
\text { Low titre specimens; } \\
\text { asymptomatic patients. } \\
\text { Specimens which may } \\
\text { contain other viral pathogens } \\
\text { Antiviral sensitivity tests. }\end{array}$ & $\begin{array}{l}\text { Swabs of lesions. } \\
\text { Cervical, urethral, } \\
\text { anorectal swabs. } \\
\text { Urine. } \\
\text { CSF, tissue; but } \\
\text { HSV-PCR preferred. }\end{array}$ & $\begin{array}{l}\text { Collection, transport } \\
\text { must retain viability. } \\
\text { Requires trained technologists. } \\
\text { Can be time consuming. } \\
\text { May or may not identify } \\
\text { HSV type. }\end{array}$ & $1-10$ days \\
\hline $\begin{array}{l}\text { Modified or } \\
\text { shell vial } \\
\text { culture }\end{array}$ & $\begin{array}{l}\text { As for culture. } \\
\text { Rapid diagnosis. }\end{array}$ & $\begin{array}{l}\text { As for culture. } \\
\text { Low yield from CSF. }\end{array}$ & $\begin{array}{l}\text { Detects only HSV, not } \\
\text { other pathogens. } \\
\text { No HSV isolate available } \\
\text { for sensitivity testing. } \\
\text { May or may not identify HSV type. }\end{array}$ & $16-48$ hours \\
\hline $\begin{array}{l}\text { Direct Detection } \\
\text { HSV antigen } \\
\text { detection }\end{array}$ & $\begin{array}{l}\text { Tests } \\
\text { High titre specimens; vesicles. } \\
\text { Immediate diagnosis. } \\
\text { Immunocompromised patients. }\end{array}$ & Swabs of lesions. & $\begin{array}{l}\text { Detects only HSV, not } \\
\text { other pathogens. } \\
\text { Less sensitive than culture. } \\
\text { May or may not identify HSV type. }\end{array}$ & $2-6$ hours \\
\hline $\begin{array}{l}\text { HSV DNA } \\
\text { detection }\end{array}$ & $\begin{array}{l}\text { High titre specimens; vesicles. } \\
\text { Immediate diagnosis. } \\
\text { Immunocompromised patients. }\end{array}$ & Swabs of lesions. & $\begin{array}{l}\text { Detects only HSV. } \\
\text { Less sensitive than culture. } \\
\text { May or may not identify HSV type. }\end{array}$ & 2-6 hours \\
\hline HSV PCR & $\begin{array}{l}\text { Low titre specimens; CSF } \\
\text { (adult or neonate), tissue. } \\
\text { Rapid, high sensitivity. }\end{array}$ & $\begin{array}{l}\text { CSF, tissue, late } \\
\text { or healing lesions. }\end{array}$ & $\begin{array}{l}\text { Detects only HSV, not other } \\
\text { pathogens. } \\
\text { May or may not identify HSV type. }\end{array}$ & 16-48 hours \\
\hline Cytology & HSV-infected cells. & $\begin{array}{l}\text { Swabs of early } \\
\text { lesions, cervical } \\
\text { swabs. }\end{array}$ & $\begin{array}{l}\text { Low sensitivity. } \\
\text { Moderate specificity. }\end{array}$ & \\
\hline Histology & $\begin{array}{l}\text { Tissue; retrospective } \\
\text { diagnosis. }\end{array}$ & Tissue. & $\begin{array}{l}\text { Low sensitivity. } \\
\text { Low specificity. }\end{array}$ & $0.5-2$ hours \\
\hline EM & $\begin{array}{l}\text { Vesicle fluid. } \\
\text { Rapid detection. }\end{array}$ & $\begin{array}{l}\text { Vesicle fluid, } \\
\text { cells or tissue. }\end{array}$ & $\begin{array}{l}\text { Low sensitivity. } \\
\text { Low specificity. }\end{array}$ & $1-24$ hours \\
\hline
\end{tabular}

HSV-2 infections are indistinguishable in their clinical presentation. ${ }^{8}$ Multiple, bilateral vesicles appear on the external genitalia 4 to 5 days after exposure, often accompanied by fever, malaise, and headache. Vesicles progress to pustules which coalesce to ulcerative lesions over the first week; their resolution in the second to third week is often accompanied by the appearance of new genital vesicles. Extragenital mucocutaneous lesions may also arise, particularly in the second week..$^{810} \mathrm{HSV}$ can be cultured from the cervix in nearly all (89\%) women; cervical abnormalities range from diffuse friability to ulcers or necrotic cervicitis. Women have a higher incidence of dysuria (83\%), urethritis (85\%), meningitis (36\%), and pharyngitis (13\%) than men $(44 \%, 27 \%, 13 \%, 7 \%$, respectively), while men and women report local pain, itching and tender inguinal lymphadenopathy with equal frequency. ${ }^{8}$ Lesions and systemic symptoms typically resolve over the course of two to three weeks. In primary infections, the virus is shed in high titres from genital lesions and cervix for a mean of 11 days. In a patient presenting relatively late in the course of a primary infection, new vesicles provide a sampling source. ${ }^{8}$

Non-primary first episodes Genital infections with HSV-2 in patients previously infected with HSV-1 ("non-primary" first episodes) are less severe than true primary infections with shorter duration of local symptoms, faster healing of lesions and a lower incidence of systemic symptoms. ${ }^{8}$ Duration of viral shedding is reduced and a lower proportion of patients develop new vesicles during their non-primary episodes. Culture of multiple sites (cervix, vulva, urine, anus) during first episodes (primary or non-primary) increases the probability of an HSV isolate. ${ }^{11}$
First episode reactivation The first clinically apparent episode of genital herpes may actually be due to reactivation of a previously silent infection..$^{13}$ Of 133 patients recently presenting to the University of Washington Viral Disease Clinic with acute first episodes of genital herpes, $23 \%$ had primary HSV-1, $41 \%$ had primary HSV-2, $14 \%$ had non-primary HSV-2, and $22 \%$ had recurrent genital infections as indicated by full Western blot antibody profiles in both acute and convalescent sera. Paired serology in conjunction with culture is the only way to determine that an acute episode is (or is not) due to recently acquired infection.

Recurrent genital herpes HSV-1 recurs much less often and in a lower percentage of patients than does genital HSV-2. ${ }^{14-16}$ Recurrence rates with the two viral types are site specific; HSV-1 simultaneously acquired in the genital tract and oral mucosa preferentially recurs orally while $\mathrm{HSV}-2$ simultaneously acquired in both sites recurs frequently in the genital tract but rarely in oral mucosa. ${ }^{17}$

Recurrent episodes with either virus type have a wide range of severity but are typically shorter than primary or non-primary first episodes with fewer, unilateral lesions and a low incidence of systemic complaints. Extragenital cutaneous lesions observed during primary or non-primary first episodes may also recur most commonly in the absence of recurrent genital lesions. ${ }^{10}$ Recurrent genital outbreaks are rarely due to reinfection with another strain of the same serotype ${ }^{18}$ but sequential infections with $\mathrm{HSV}-1$ and HSV-2 have been reported and may affect the apparent response to antiviral therapy in these patients. ${ }^{19}$ Such cases have been identified by viral culture and typing of isolates.

Early, vesicular lesions from first episodes 
or recurrences contain the most virus and have the highest probability for positive results in HSV direct antigen or DNA detection tests. ${ }^{20-22}$ Later pustular or ulcerative lesions require amplification of the virus by culture; crusted, healing areas have little antigen or viable virus and may be positive only by HSV-PCR. ${ }^{23}$ Because HSV is highly cell associated, vigorous swabbing is necessary to obtain infected cells from the base of lesions. ${ }^{24}$

Genital herpes in immunocompromised patients Primary or recurrent genital infections in immunosuppressed patients or in those with AIDS can result in extensive involvement of mucocutaneous sites, prolonged virus shedding and, in some cases, dissemination to multiple organs. ${ }^{25-27}$ Candidates for immunosuppressive regimens should be screened by HSV serology so that prophylactic antiviral therapy can be considered. ${ }^{6}$ Symptomatic patients are good candidates for HSV direct detection tests because of their high HSV titres and their need for rapid diagnosis. However, it should be recognised that these tests diagnose exclusively HSV; cell culture is needed to diagnose other pathogens such as respiratory syncytial virus, cytomegalovirus, adenovirus, varicella zoster and enteroviruses. ${ }^{28}$ Culture also provides an isolate for antiviral sensitivity testing. ${ }^{29}$

Asymptomatic or unrecognised genital herpes. Perhaps the greatest diagnostic challenge for clinicians and laboratories, alike, is that of atypical or asymptomatic genital herpes infections. Studies with accurate type-specific serologies indicate that $20-35 \%$ of middle class populations and as many as $65-80 \%$ of selected populations in the United States have been infected with HSV-2;30-32 yet, most have no history of genital herpes. ${ }^{31-33}$ Predisposing factors for asymptomatic acquisition remain largely unknown. Individuals with prior antibodies to HSV-1 are less likely than seronegative persons to acquire $\mathrm{HSV}-2$ infections $^{34}$ and of those who do become infected, HSV-1 seropositive patients are more likely to have clinically inapparent HSV-2 genital infections. ${ }^{3132}$ Asymptomatic shedding is most frequent in the months after primary infection and HSV shedding is more frequent after primary HSV-2 than after primary HSV1 infections. ${ }^{16}$ Asymptomatic shedding is also less frequent after non-primary genital HSV-2 than after primary HSV-2 infection. ${ }^{16}$

Asymptomatic genital herpes can be detected in high risk populations by culture of multiple sites ${ }^{11}$ or, less often, by HSV direct antigen detection methods. ${ }^{35}$ The sporadic nature of HSV reactivation events, low virus titres, and brief duration of shedding all mitigate against laboratory detection of virus. ${ }^{281636}$ Type-specific serologies can identify asymptomatic HSV-2 carriers irrespective of viral shedding. ${ }^{11}$

In addition to asymptomatic infections, mild or atypical genital herpes infections may not be recognised by either patient or clinician. ${ }^{37}$ Genital herpes may present in women as vulvar fissures, furuncles, or non-specific erythema. ${ }^{1126}$ Patients also may present with cervicitis, proctitis, arthralgia or meningitis without vesicular genital lesions. ${ }^{2638}$ Conversely, genital herpetic ulcers may be mistaken for those caused by other sexually transmitted agents. ${ }^{2039}$ In all of these cases, a diagnosis of genital herpes is best established by laboratory testing; most reliably, HSV culture.

Genital herpes in pregnancy Genital herpes infections acquired in pregnancy present a risk to the mother, to the pregnancy and to the fetus. ${ }^{4041}$ Neonates exposed to HSV in the maternal birth canal during parturition or, less commonly, to HSV after birth, are at risk for developing potentially fatal HSV infections. ${ }^{41}$ Management of pregnant women encompasses three areas of concern: (1) identifying pregnant women at risk of acquiring genital herpes before delivery so that transmission to the mother can be prevented; (2) identifying mothers with subclinical genital herpes so that evidence of neonatal HSV exposure can be sought at term, and (3) screening those with known infections to identify asymptomatic shedding during labour and delivery. ${ }^{42} 43$

(1) Asymptomatic mothers who have acquired genital herpes shortly before delivery are at tenfold greater risk of transmitting the virus to their neonates than are those with asymptomatic recurrent $\mathrm{HSV}-2$ shedding at term. ${ }^{445}$ Prenatal serology by most available methods can accurately identify HSV seronegative women. Seronegative mothers whose partners have history or serological evidence of oral or genital herpes should be counselled to avoid genital contact with their partner's oral or genital secretions. ${ }^{46}$ Only type specific serologies can identify women with HSV-1 antibodies who might acquire HSV-2 from their partner. ${ }^{43}{ }^{46}$ Culture at term may be indicated for seronegative women with high risk behaviors for genital HSV infection during pregnancy. Given the relatively high risk to the infant of maternal firstepisode genital infection, women who are culture-positive at term should have serologic testing by methods which allow seroconversion to be detected; infants whose mothers have had recent infections require careful monitoring for neonatal infection. ${ }^{43}$

(2) Type specific serologies are also necessary to accurately identify women with silent HSV-2 infections who might asymptomatically shed HSV-2 at delivery. Although such women have low transmission rates compared with newly infected women, cervical and vulvar cultures should be performed at term on HSV-2 seropositive women to identify neonates who may have been exposed to the virus. ${ }^{44}$ Where type specific serology is unavailable, women who are seropositive to HSV by conventional methods can be cultured during labour. A less costly alternative is to culture women at high risk of having genital herpes; those with histories of multiple partners or past sexually transmitted diseases.

(3) Women with histories of genital her- 
pes should be carefully examined for typical or atypical lesions at term. Rapid tests such as cytology or HSV direct antigen detection can be performed on such lesions with the understanding that these tests are $75 \%$ as sensitive as culture for vesicular lesions and much less sensitive for atypical lesions or asymptomatic screening. HSV-PCR can also detect asymptomatic HSV at term. ${ }^{47}$ However, at present, viral culture of vulva and cervix at term (not antenatally) is the most accurate and practical way to document neonatal exposure to HSV. ${ }^{48}$ Selective use of prenatal or postnatal serology, intrapartum culture, and careful history comprise consensus guidelines from scientists studying risk factors for neonatal herpes. ${ }^{43}$

Diagnostic testing of neonates. Monitoring healthy exposed neonates according to the serological status of the mother and prompt diagnosis of the infected infant are important for initiating effective antiviral therapy. ${ }^{43}$ Neonates exposed to HSV from a maternal HSV recurrence should be monitored closely for signs of infection; surveillance cultures are not widely used. Neonates exposed to HSV from a maternal infection acquired close to term are at higher risk and should have HSV cultures of throat, conjunctiva, urine, rectum and cerebrospinal fluid (CSF). Positive cultures dictate antiviral therapy. CSF positive by HSV-PCR is diagnostic for neonatal infection; ${ }^{49}$ the predictive value of positive HSVPCR results from other sites remains to be defined. Serologic diagnosis in acutely ill infants is complicated in conventional tests by maternal antibody and by inefficient IgM production in neonates. ${ }^{42}$ Western blot can differentiate maternal and neonatal antibody profiles when specimens are tested and read in parallel..$^{50}$

\section{Laboratory techniques to detect HSV \\ Viral culture}

Isolation of HSV in cell culture is the "gold standard" diagnostic test for acute HSV infections, allowing extended observation, optimal sensitivity, and production of hightiter HSV isolates for antiviral sensitivity ${ }^{29}$ or DNA restriction enzyme testing. ${ }^{22}$ Most culture systems also detect pathogens other than HSV. ${ }^{28}$ Human diploid fibroblast lines such as MRC-5 and WI-38 are widely available and well characterised for HSV growth. Some studies suggest that mink lung cells, guinea pig embryonic fibroblasts, primary rabbit kidney cells, and rhabdomyosarcoma cells are more sensitive and result in more rapid diagnosis from a higher proportion of specimens. ${ }^{24}$

HSV strains will replicate in most cell lines in 12-18 hours with resulting CPE as early as 16-24 hours after inoculation. With daily observation, the median time to CPE is 2-3 days. Approximately $5 \%$ of specimens require more than 7 days to develop CPE, even in highly sensitive cell lines; for maximal sensitivity, cultures should be observed for 10-14 days.

a. Culture Confirmation: CPE resembling that of HSV may be due to unrelated viruses or to toxic effects of specimens such as urine, semen, or rectal swabs. ${ }^{51}$ Confirmatory tests provide the only acceptable identification of a presumptive HSV isolate. These tests are based on viral neutralisation with hyperimmune sera or may be HSV antigen detection methods based on fluorescent antibody or enzyme-linked antibody binding. Rapid and simple tests based on latex agglutination or solid phase formats are available commercial$1 y^{5253}$ as are HSV DNA confirmatory tests. ${ }^{54}$

b. HSV typing. HSV-1 and HSV-2 can be differentiated by their growth characteristics ${ }^{55}$ and their sensitivity to antiviral compounds. ${ }^{56}$ Most laboratories, however, determine the isolate type as part of their HSV confirmatory testing by using monoclonal antibodies directed to type specific antigens in enzyme immunoassay (EIA) ${ }^{57}$ or fluorescence immunoassay (FA) formats. ${ }^{559}$ These methods have been validated against molecular subtyping by DNA restriction endonuclease profiles $^{5760}$ or protein profiles ${ }^{6162}$ and the necessary reagents are widely available. ${ }^{63}$ Because of their accuracy and simplicity, type-specific antigen detection tests are rapidly supplanting confirmation methods based on neutralisation or passive haemagglutination inhibition.

Liquid or in situ hybridisation of type-specific DNA probes is another sensitive and accurate method for typing HSV isolates. However, commercial development of these tests has not been as extensive or as rapid as that of antigen detection tests. ${ }^{54}$

c. Modified culture techniques: Several modifications to standard culture practices have been reported to increase the speed or sensitivity of HSV detection. ${ }^{64} 65$ The most widely used technique involves centrifuging the specimen onto susceptible cells to increase the efficiency of infection and speed of detection. ${ }^{66}$

Combining culture with HSV antigen detection techniques allows both the amplification of inoculated virus by growth in culture and the rapid and specific detection of HSV before CPE develops (table 1). Specimens are centrifuged onto cell monolayers on coverslips ("shell vial") or 24-48 well plates. After 16 to 48 hours, coverslips are removed or wells are selected to test for HSV antigens ${ }^{67}$ or DNA. ${ }^{68}$ Some, not all, modified culture techniques are as sensitive as standard culture. Viral pathogens other than HSV are not detected. ${ }^{64}$

HSV direct detection tests: While cell culture techniques are unsurpassed in their sensitivity, these tests may take days to accomplish. HSV in acute infections or in immunocompromised patients require a more rapid laboratory diagnosis to guide antiviral therapy and infection control efforts. Cytology, visualisation by electron microscopy, and HSV antigen or DNA detection techniques have all been applied to the diagnosis of HSV directly from specimens, without intervening amplification steps (table 1).

a. Cytology. Cytological diagnosis depends upon the detection of an infected cell from 
scrapings from oral or genital lesions which have been stained by Papanicolaou or WrightGiemsa (Tzanck stain). ${ }^{69} 70 \mathrm{HSV}$ causes cells to enlarge and, in some cases, to fuse into multinucleated giant cells. ${ }^{22}$ Intranuclear inclusions can also be observed with proper staining. The same effects can be observed in HSV infected tissues that have been prepared and stained for histology. These tests are rapid, less costly, require less experience to screen than culture and do not depend upon HSV viability in the specimen. However, the cytopathic effect observed cannot be distinguished from that caused by other viruses such as varicella-zoster virus; a potential problem in immunosuppressed patients. Cytological techniques are only $30-80 \%$ as sensitive as culture for HSV from genital lesions. ${ }^{22}$

b. Electron microscopy. Electron microscopy (EM) for visualization of negatively stained HSV virions from vesicle fluid is rapid but requires expensive equipment and trained personnel to perform. Thin sectioning is required to detect intracellular HSV. Sensitivity of EM is low and herpes simplex virions cannot be distinguished from other herpes virions such as varicella zoster.

c. HSV antigen detection. Detection of HSV antigen has been accomplished in fixed cells by the binding of antibodies conjugated with fluorescent dyes (direct fluorescent antibody or "DFA" tests) or enzymes such as peroxidase (immunoperoxidase or "IP" tests). Newer methods use solubilised infected cells and solid-phase enzyme immunoassay formats for rapid testing which does not rely on the integrity of sampled cells for accuracy. ${ }^{71-73}$ The reported sensitivity of any direct antigen test is influenced by the HSV prevalence in the test population, the nature of the specimens tested, and the study design used to derive performance data. In general, HSV direct antigen tests are less sensitive than culture for specimens from asymptomatic patient populations due, in large part, to low virus titres. ${ }^{35} 7374$ However, for detecting HSV in lesions, sensitivity of direct antigen tests can equal or exceed that of culture. ${ }^{7172}$ Parenthetically, direct detection of HSV glycoproteins in CSF has been used to diagnose HSV encephalitis; $;^{75}$ however, this particular application is not widely available.

d. HSV DNA detection. The application of DNA hybridisation techniques to rapid HSV detection has been aided by the development of nonradioactive biotinylated HSV DNA probes. Sensitivity of HSV DNA detection can equal that of HSV antigen detection tests or culture for lesions but not for asymptomatic shedding of HSV. ${ }^{68}{ }^{76-79} \mathrm{HSV}$ typing can now be incorporated into HSV direct detection methods. ${ }^{80}$ Because DNA is quite stable, DNA detection methods are appropriate for specimens which cannot be transported under the stringent conditions required for culture. ${ }^{5}$

e. HSV-PCR. Just as antigen detection techniques can be made more sensitive by amplifying the available antigen by viral replication in cell culture, DNA amplification can be accomplished in vitro by the polymerase chain reaction. In this technique, DNA from the patient's specimen is denatured and allowed to anneal to complementary DNA fragments ("primers") which bracket a small region of conserved HSV DNA. The primers are extended by a heat stable polymerase to yield a complete DNA copy. The reaction mixture is then denatured and another cycle of primer binding and elongation is allowed to proceed. Multiple cycles result in rapid, exponential amplification of the DNA fragment of interest. ${ }^{23}$

HSV-PCR of CSF is an excellent noninvasive method to diagnose herpes encephalitis in adults and neonates ${ }^{49182}$ or other central nervous system disorders due to HSV. ${ }^{83} 84$ HSV-PCR is far more sensitive than viral culture $^{84}$ or HSV antibody determination in CSF (table 1). HSV-PCR is not widely available during to the need for special containment laboratories and instrumentation, high level technical expertise, and the exhaustive quality control required to avoid contamination and amplification of non-viral DNA. ${ }^{85} 86$

\section{Serological techniques to detect HSV antibodies} General considerations

The appropriate use of serology depends upon the test format and the clinical presentation (table 2). With symptomatic patients, viral culture and/or antigen detection are the tests of choice. However, acute and convalescent serum antibody titres by many methods can demonstrate seroconversion during primary episodes when viral cultures are unavailable or sampling is suboptimal. Seroconversion in a pregnant women who is shedding HSV from the genital tract at term indicates high risk of neonatal infection. ${ }^{43}$ Seroconversion is not always easy to demonstrate. Patients receiving acyclovir for their primary episodes have a blunted immune response; convalescent sera may have little detectable HSV antibody. ${ }^{87-89}$ Further, titre rises in non-primary first episode genital HSV-2 are predominantly anamnestic responses to type common determinants on HSV-1; HSV-2 antibody responses are masked in many methods. ${ }^{90}$ Since titre rises are rarely demonstrable with recurrent episodes, ${ }^{14}$ stable antibody titres in a patien without history of genital herpes indicate a first symptomatic episode due to HSV reactivation.

HSV antibodies appear in cerebrospinal fluid of neonates or adults with herpes encephalitis. However, detectable titres may take days to develop. ${ }^{91}$ Moreover, positive antibody results from CSF must be interpreted with care due to the possible transit of serum antibodies across compromised blood brain barriers, ${ }^{91}{ }^{92}$ HSV-PCR is the test of choice for HSV encephalitis.

One of the main demands for HSV serology is to diagnose asymptomatic HSV infection. This is of particular value to identify patients who should receive prophylactic antiviral therapy after bone marrow or organ transplant or while undergoing other 
Table 2 HSV serologic assays

\begin{tabular}{|c|c|c|c|}
\hline Method & Appropriate Use & Limitations & Time Required \\
\hline $\begin{array}{l}\text { Biologic Assays } \\
\text { (Nt, CF) }\end{array}$ & $\begin{array}{l}\text { Seroconversion in seronegative } \\
\text { patients. } \\
\text { As adjunct to HSV detection. }\end{array}$ & $\begin{array}{l}\text { Most require live HSV. } \\
\text { Cumbersome; can't automate. } \\
\text { Inaccurate for determining } \\
\text { antibody type. } \\
\text { Can't detect seroconversion } \\
\text { in nonprimary infections. }\end{array}$ & $1-6$ days \\
\hline $\begin{array}{l}\text { Solid phase } \\
\text { Assays } \\
\text { (RPHA, EIA, IFA) }\end{array}$ & $\begin{array}{l}\text {-Seroconversion in seronegative } \\
\text { patients. } \\
\text { As adjunct to HSV detection. }\end{array}$ & $\begin{array}{l}\text { Inaccurate for determining } \\
\text { antibody type. } \\
\text { Can't detect seroconversion } \\
\text { in nonprimary infections. }\end{array}$ & $2-5$ hours \\
\hline $\begin{array}{l}\text { Protein specific } \\
\quad \text { assays }(\mathrm{gC}-1, \mathrm{gG})\end{array}$ & $\begin{array}{l}\text { Screening to identify subclinical } \\
\text { HSV-1 or HSV-2. } \\
\text { Seroconversion in nonprimary infections. }\end{array}$ & $\begin{array}{l}\text { Require purified proteins or } \\
\text { capture methods. } \\
\text { Seroconversion to gG not universal. } \\
\text { Can't distinguish oral and genital } \\
\text { HSV-1 infections. } \\
\text { Limited availability. }\end{array}$ & $2-5$ hours \\
\hline Western blot assay & $\begin{array}{l}\text { Screening to identify subclinical } \\
\text { HSV-1 or HSV-2. } \\
\text { Seroconversion in nonprimary infections. } \\
\text { Distinguishing acute from reactivation } \\
\text { infections. } \\
\text { Distinguishing neonatal from maternal } \\
\text { antibody. }\end{array}$ & $\begin{array}{l}\text { Requires Western blot technology; } \\
\text { can't automate. } \\
\text { Can't distinguish oral and } \\
\text { genital HSV-1 infections. } \\
\text { Limited availability. }\end{array}$ & 1-5 days \\
\hline
\end{tabular}

immunosuppressive regimens. HSV serologies have also been used to identify individuals with antibodies to HSV-2, presumably due to genital infection. ${ }^{3146}$ Most serological tests offer mathematic formulae to indicate the predominance of antibody reactivity against one HSV subtype over the other. In theory, these methods should work well for patients who have been infected with a single HSV type but, in fact, these methods can indicate antibodies to the wrong HSV type because of the extensive cross-reactivity between the immunogenic proteins of HSV-1 and HSV-2. Presence of antibodies to both HSV-1 and HSV-2 in patients with dual infections cannot be identified by formulae which infer HSV type by predominance of reactivity. ${ }^{90}$

\section{Functional antibody assays}

a. Neutralizing antibody assays (Nt): Antibodies which neutralise the ability of HSV to infect cells are detected by incubating serial dilutions of the test serum with a fixed titre of challenge virus then adding the mixture to permissive cells. The presence of neutralising antibody is inferred from the reduction CPE or by the reduction in macroscopic "plaques" which develop via cell-tocell spread of the virus under an agar overlay. ${ }^{93}$ Titre is determined by the serum dilution which results in $50 \%$ reduction in CPE or plaque number. Both complement independent and complement dependent $\mathrm{Nt}$ tests are used to detect HSV antibodies. Both formats are time consuming, require live virus, and are not easily adaptable to testing large numbers of sera.

A ratio of the antibody titres to $\mathrm{HSV}-1$ and HSV-2 has been used to indicate the HSV type of the antibodies detected. An alternative typing method compares the potency of neutralisation ( $\mathrm{pN}$ ) of HSV-1 and HSV-2 with an adjustment for the working titers of the HSV strains used. ${ }^{94}$ Intermediate values in either calculation cannot be interpreted accurately and have been considered "type indeterminate". ${ }^{95}$ The assumption that type indeterminate neutralising assay are due to the presence of antibodies to both $\mathrm{HSV}-1$ and HSV-2 has not been borne out; as many as $40 \%$ of sera with type indeterminate neutralising antibodies contain only HSV-1 antibodies by Western blot (Ashley et al, submitted manuscript).

b. Complement fixation (CF): Standard tests for complement fixing antibodies can detect HSV antibodies within the first 2 weeks after onset of infection. Unless the laboratory performs CF tests for other agents, CF is not likely to be offered as it is more cumbersome than other serologies without increased sensitivity. Some patients have anticomplement antibodies in their sera which interfere with the test and subtyping of HSV antibodies is not usually attempted.

c. Antibody dependent cell cytotoxicity ( $A D C C):$ ADCC assays use HSV-infected target cells which are radiolabelled with ${ }^{51} \mathrm{Cr}$. Serum antibody binds to the viral glycoproteins expressed on the surface of the target cells. In turn, HSV-primed killer cells bind to the antibody via Fc receptors. The extent of target cell cytotoxicity is determined by the amount of ${ }^{51} \mathrm{Cr}$ released. ADCC antibodies can be detected well before $\mathrm{Nt}$ antibodies arise. ${ }^{96}$ However, ADCC tests are exacting to perform, detect only IgG, require radioactivity, and, for these reasons are not generally used for diagnosis.

Solid phase binding assays. Assays have been developed using a variety of solid phase substrates including red blood cells (RBC), latex beads, and infected cell monolayers to present HSV antigen. The character of the tests is influenced by the signal used: radioactivity (radioimmunoassay), fluorescence (indirect fluorescent antibody assays), or enzyme-substrate colour development (enzyme immunoassays).

a. Reverse passive haemagglutination (RPHA): These tests utilise red blood cells sensitised with HSV-1 or HSV-2 proteins which are reacted in microtitre wells with serial dilutions of sera. Antibodies to HSV bind and agglutinate the cells within 2 to 3 hours. Positive wells are macroscopically distinguished by the disbursed pattern of the agglu- 
tinated RBC. A more sensitive modification uses an antigen capture format with $\mathrm{RBC}$ sensitised with monoclonal antibodies to HSV-1 and HSV-2. ${ }^{97}$ The antigen is preincubated with the sensitised RBC and serves as a bridge to bind serum antibody resulting in larger lattices for a given antibody titre. Antibody titres in these tests correlate well with those from neutralisation tests. ${ }^{98}$

b. Indirect fluorescent antibody assays (IFA): These tests use fluorescein labelled antihuman secondary antibodies to detect antibodies from serially diluted serum samples which are bound to HSV proteins expressed in acetone fixed, infected cells. An advantage of this approach is the specificity offered by the distinctive staining pattern of antibodies bound to the viral proteins in infected cells. ${ }^{59} 60$ Non-specific binding that might be interpreted as specific signal in a colourimetric test such as EIA (see below) can be discerned by its random staining pattern in whole-cell IFA tests. However, skilled readers are required and the tests are not as amenable to automation. A number of commercial suppliers now have kits available for HSV IFA.

c. Enzyme immunoassays (ELA): A third type of antibody binding assay uses enzymelabelled secondary antibodies to detect serum antibodies bound to HSV-1 or HSV-2 protein preparations (EIA). These tests most commonly use microtitre plates as a substrate for the antigen but latex beads are also used. Bound antibodies are detected by sequential binding of an enzyme linked secondary antibody and the resulting coloured product of a reaction catalysed by the enzyme. These are the most widely used commercial HSV serologies in the United States because of the ease of their performance, automation capabilities, and comparatively low cost. These tests can accurately differentiate seronegative from seropositive samples and can demonstrate seroconversion to $\mathrm{HSV}$ in patients with primary infections. ${ }^{90}$

d. Antibody typing by IFA or ELA: Solid phase binding assays which use crude preparations of $\mathrm{HSV}$ antigens are often used inappropriately for $\mathrm{HSV}$ antibody typing. We found that among 40 patients with culture documented first episode genital HSV-1 or HSV-2, seroconversion to the correct HSV subtype was demonstrated in only $33-75 \%$ of patients, depending upon which of three EIA kits was used. HSV-2 antibodies were not detected in $58-76 \%$ of patients presenting with recurrent HSV-2 who had antibodies to both HSV-1 and HSV-2 by Western blot. ${ }^{90}$ Seroconversion to HSV-2 in the HSV-1 seropositive patient is particularly problematic in these tests owing to strong anamnestic responses to HSV type common epitopes..$^{9099}$ This effect was seen as rising levels of HSV-1 reactive antibody in convalescent sera of patients with HSV-2 infections. Without typing of the patients' HSV isolates, results from these serum pairs would have been interpreted, by kit criteria, as consistent with primary HSV-1 infection. Antibody typing by these tests is not recommended.
Type-specific immunoassays. Serologies for type specific antibodies have been valuable for diagnosing asymptomatic semen donors, ${ }^{100}$ pregnant women ${ }^{45}$ and sexually active individuals ${ }^{17}$ at risk of transmitting genital HSV-2 infections.

a. Protein-specific immunoassays: These tests use proteins with predominantly typespecific epitopes in a solid phase EIA. In particular, viral envelope glycoproteins from HSV-1 (gG-1 or gC) or HSV-2 (gG-2) have been used as test antigens. ${ }^{101-106}$ The source of gG varies; affinity chromatography from infected cell lysates using Helix pomatia lectin or gG-specific monoclonal antibody ligands results in purified glycoprotein which retains the epitopes dependent on native structure. Assays based on recombinant DNA-derived gG-1 or gG-2 ${ }^{107} 108$ provide high levels of purified $\mathrm{gG}$ but may not allow glycosylation which may result in loss of important epitopes.

One format which has performed well in typing HSV antibodies is the immunodot enzyme assay which employs nitrocellulose disks as the antigen substrate. The assay is carried out in parallel in 96-well microtitre plates containing $\mathrm{HSV}-1$ or $\mathrm{HSV}-2 \mathrm{gG}$. Serum is incubated overnight and, after thorough washing, a solid phase EIA is performed. ${ }^{103} 104$ Other formats use a capture antibody bound to microtitre wells ${ }^{105}$ or immunoblots of gG-2. ${ }^{106}$

These tests are accurate and simple to perform even on large numbers of sera. Their major drawback is that antibody to gG-2 may not develop for 6-8 weeks after infection and, in a small group of patients (5-10\%), gG antibody remains undetectable. ${ }^{109}$ In one study, a high proportion of AIDS patients with culture-proven recurrent HSV infections were falsely negative for antibody to gG-2. ${ }^{110}$ Few investigators have developed proteinspecific serologies for HSV-1 antibodies; $;^{101} 104$ yet, testing for both HSV-1 and HSV-2 provides the most complete serologic profile for diagnosing first episodes and for demonstrating past infection. General availability of these tests awaits commercial development.

b. Western blot ("immunoblot"): Antibodies to as many as 50 individual proteins, including $\mathrm{gG}$, can be detected by immunoprecipitation of radiolabelled crude HSV protein preparations (RIPA) ${ }^{111}$ or by reacting sera with electrophoretically separated proteins that have been transferred to nitrocellulose $^{112}$ or polyvinylidene difluoride ("ECL-Western blot"). ${ }^{113}$ The Western blot is preferred to RIPA because radioactive reagents are not needed and because antigen and blots can be prepared in bulk for interrun reproducibility. We have refined and exhaustively tested the Western blot assay to establish its ability to detect early seroconversion and its accuracy in typing HSV antibodies (fig). In this test, predominant binding to denatured HSV-1 or HSV-2 proteins along with recognition of type specific bands such as gG-2 and ICP35 provides the basis for antibody subtyping (fig). When test results 
Figure Documentation of HSV seroconversion by Western blot. Sera were drawn at $1,3,6,30$, and 52 weeks after onset of primary genital $\mathrm{HSV}-2$ and reacted with blots containing $H S V-1$ proteins (left-side blot in each pair) and $H S V-2$ proteins (rightside blots). Blots at 3 weeks lack the bands to definitively type the antibodies. By 6 weeks, a clear $H S V-2$ profile can be discerned, including $a$ gG-2 band. By 30 weeks, antibodies to ICP35 are detectable. The patient received $200 \mathrm{mg}$ of acyclovir 5 times daily for 10 days during his primary episode.

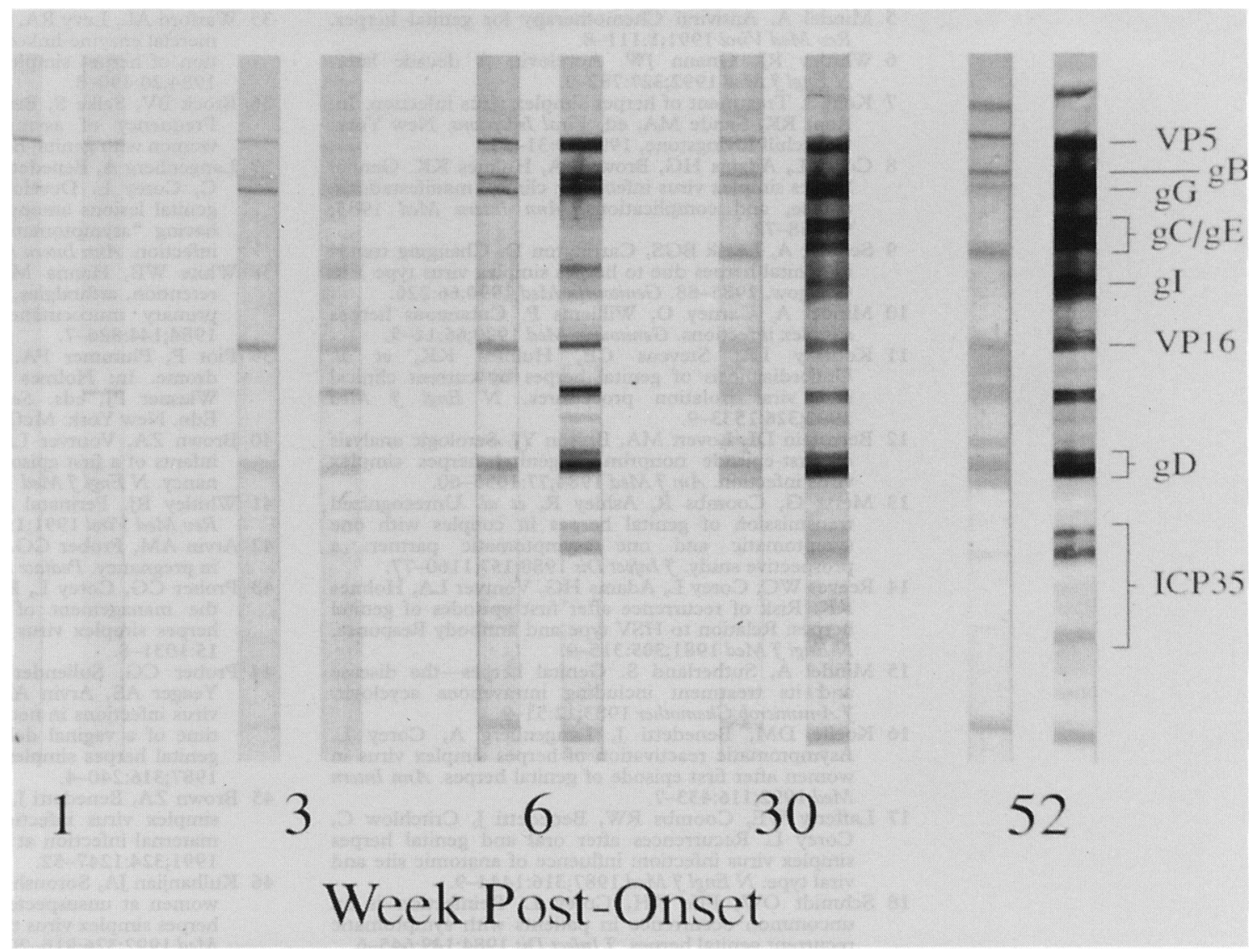

are unclear, the type specific antibodies in the specimen are removed by batch adsorption against sepharose-bound HSV-1 and HSV-2 proteins and the adsorbed serum preparations are retested on fresh $\mathrm{HSV}-1$ and HSV-2 blots. ${ }^{24}$ These procedures can identify HSV-2 antibodies even when those against gG-2 are not detectable. ${ }^{109112}$ Adsorption can often "unmask" antibodies against gG-2 which comigrate, in part with gB. ${ }^{89}$ Over $95 \%$ of sera can be definitively typed by Western blot with results that agree with $\mathrm{HSV}$ isolate type in $\mathbf{7 9 8 \%}$ of symptomatic patients and with gGspecific tests in $>94 \%$ of asymptomatic patients. ${ }^{112}$

The Western blot method offers a distinct advantage in its ability to detect seroconversion to HSV-2 in patients with prior HSV-1. In this common scenario, the early anamnestic responses to type common epitopes is apparent in convalescent sera reacted with HSV-1 blots but, in addition, HSV-2 specific reactivity can be detected. ${ }^{5112}$ Commercial testing by Western blot and gG-specific serologies, is limited to a few laboratories.

\section{Future directions for HSV laboratory diagnosis} The field of HSV laboratory diagnosis has enjoyed a rapid increase in the number and types of methods available. Improvements in the standard culture of HSV have already lead to more rapid, yet accurate, techniques based on antigen detection. These techniques are still being improved with better detector systems for greater sensitivity. HSV DNA detection with or without culture amplification may become more widely used owing to the high degree of specificity conferred by hybridisation, improving sensitivity, growing availability of newer nonradioactive signal systems, and rapid result time possible. Wider availability of type specific probes will be binding.

The need for highly sensitive techniques is likely to be met by HSV-PCR which already has supplanted other diagnostic methods for herpes encephalitis in some centres. At this time, HSV-PCR is not applicable to situations requiring truly rapid diagnosis; for example, to detect HSV shedding in pregnant women prior to delivery. For less urgent situations, incorporation of rapid techniques to detect amplified DNA is already reducing the

With respect to serology, the clear need is for wider availability of accurate and sensitive type specific serologies. Recombinant DNA technology should provide the critical reagents to make protein-specific or immunoblot serologies more widely available. Current research identifying type specific epitopes on major HSV immunogens should result in type specific antigen mixtures to improve accuracy of antibody detection. described $^{113}$ and await commercial development.

1 Rooney JF, Felser JM, Ostrove JM, Straus SE. Acquisition of genital herpes from an asymptomatic sexual partner. N Engl f Med 1986;314:1561-4.

2 Barton SE, Davis JM, Moss VW, Tyrus AS, Munday PE. Asymptomatic shedding and subsequent transmission of genital herpes simplex. Genitourin Med sion of genital

3 Mertz GJ, Schmidt O, Jourden JL, et al. Frequency of acquisition of first-episode genital infection with herpes simplex virus from symptomatic and asymptomatic

4 Whitley RJ, Nahmias AJ, Visintine AM, Fleming CL, Alford CA. The natural history of herpes simplex virus 1980;66:489-94. important if DNA techniques are to replace antigen detection by monoclonal antibody time required for HSV-PCR. High-sensitivity detection signals have been source contacts. Sex Trans Dis 1985;12:33-9. infection of mother and newborn. Pediatrics 
5 Mindel A. Antiviral Chemotherapy for genital herpes. Rev Med Virol 1991;1:111-8.

6 Whitley RI, Gnann JW. Acyclovir: A decade later. N Engl F Med 1992;327:782-9.

7 Kohl S. Treatment of herpes simplex virus infection. In Root RK, Sande MA, ed. Viral Infections. New York: Churchill Livingstone, 1993;10:31-55.

8 Corey L, Adams HG, Brown ZA, Holmes KK. Genital herpes simplex virus infections: clinical manifestations, course, and complications. Ann Intern Med 1983; 98:958-72.

9 Scoular A, Leask BGS, Carrington D. Changing trends in genital herpes due to herpes simplex virus type 1 in Glasgow, 1985-88. Genitourin Med 1990;66:226.

10 Mindel A, Carney O, Williams P. Cutaneous herpes simplex infections. Genitourin Med 1990;66:14-5.

11 Koutsky LA, Stevens CE, Holmes $\mathrm{KK}$, et al. Underdiagnosis of genital herpes by current clinical and viral isolation procedures. $N$ Engl $f \mathrm{Med}$ and viral isolation

12 Bernstein DI, Lovett MA, Bryson YJ. Serologic analysis of first-episode nonprimary genital herpes simplex virus infection. Am $₹$ Med 1984;77:1055-60.

13 Mertz G, Coombs R, Ashley R, et al. Unrecognized transmission of genital herpes in couples with one symptomatic and one asymptomatic partner: a prospective study. F Infect Dis 1988;157:1 160-77.

14 Reeves WC, Corey L, Adams HG, Vontver LA, Holmes KK. Risk of recurrence after first episodes of genital herpes: Relation to HSV type and antibody Response. N Engl F Med 1981;305:315-9.

15 Mindel A, Sutherland S. Genital herpes-the disease and its treatment including intravenous acyclovir. an Antimicrob Chemother 1983;12:51-9.

16 Koelle DM, Benedetti J, Langenberg A, Corey L. Asymptomatic reactivation of herpes simplex virus in women after first episode of genital herpes. Ann Intern women after first episod

17 Lafferty WE, Coombs RW, Benedetti J, Critchlow C, Corey L. Recurrences after oral and genital herpes simplex virus infection: influence of anatomic site and viral type. $N$ Engl $¥$ Med 1987;316:1444-9.

18 Schmidt OW, Fife $\mathrm{KH}$, Corey $\mathrm{L}$. Reinfection is an uncommon occurrence in patients with symptomatic recurrent genital herpes. F Infect Dis 1984;149:645-6.

19 Samarai AM, Shareef AA, Kinghorn GR, Potter CW. Sequential genital infections with herpes simplex virus types 1 and 2. Genitourin Med 1989;65:39-41.

20 Corey L, Holmes KK. Genital herpes simplex virus infections: Current concepts in diagnosis, therapy, and infections: Current concepts in diagnosis, the

21 Lafferty WE, Krofft S, Remington M, et al. Diagnosis of herpes simplex virus by direct immunofluorescence and viral isolation from samples of external genital and viral isolation from samples of external genital lesions in a high pre

22 Fife KH and Corey L. Herpes Simplex Virus. In: Holmes KK, Mardh PA, Sparling PF, Wiesner PJ, eds. Sexually Transmitted Diseases 2nd ed. New York: McGraw Hill Publishers, 1989;941-52.

23 Cone RW, Hobson AC, Palmer J, Remington M, Corey L. Extended duration of herpes simplex virus DNA in genital lesions detected by the polymerase chain reaction. F Infect Dis 1991;164:757-60.

24 Ashley R, Corey L. Herpes Simplex Viruses and B Virus. In: Schmidt NJ, Emmons R, eds. Diagnostic Procedures for Viral, Rickettsial and Chlamydial Infections, 6th Ed. Wor Viral, Rickettsial and Chlamydial Infections, 6th Ed. Washingt

25 Lane HC, Fauci AS. Infectious complications of AIDS. In: Broder S, ed. AIDS: Modern Concepts and Therapeutic Challenges. New York: Marcel Dekker, 1987;185-203.

26 Corey L. Genital Herpes. In: Holmes KK, Mardh PA, Sparling PF, Wiesner PJ, eds. Sexually Transmitted Diseases 2nd Ed. New York: McGraw Hill, 1989; 391-413.

27 Whitley RJ. Herpes simplex viruses. In: Fields BN, Knipe DM, eds. Field Virology, 2nd Ed. Raven Press, 1990;2:1843-87.

28 Hughes JH, Mann DR, Hamparian VV. Viral isolation versus immune staining of infected cell cultures for the versus immune staining of infected cell cultures for the laboratory diagnosis of herpes sim.

29 Parr DP, Straus SE. Antiviral resistance among herpes viruses. Infect Dis Clin Prac 1992;1:21-7.

30 Johnson RE, Nahmias AJ, Magder LS, Lee FK, Brooks CA, Snowden CB. A seroepidemiologic survey of the prevalence of herpes simplex virus type 2 infection in the United States. N Engl $\mathscr{F}$ Med 1989;321:7-12.

31 Koutsky L, Ashley R, Homes $\mathrm{K}$, et al. The frequency of unrecognized type 2 herpes simplex virus infection among women: implications for the control of genital herpes. Sex Trans Dis 1990;17:90-4.

32 Breinig MK, Kingsley LA, Armstrong JA, Freeman DJ, Ho M. Epidemiology of genital herpes in Pittsburgh: serologic, sexual, and racial correlates of apparent and inapparent herpes simplex infections. F Infect Dis

33 Stavraky KM, et al. Sexual and socioeconomic factors affecting the risk of past infections with herpes simplex affecting the risk of past infections with herpe
virus type 2 . Am f Epidemiol 1983;118:109.

34 Mertz GJ, Benedetti J, Ashley R, Selke S, Corey L. Risk factors for sexual transmission of genital herpes. Ann
35 Warford AL, Levy RA, Rekrut KA. Evaluation of a commercial enzyme-linked immunosorbent assay for detection of herpes simplex virus antigen. $\mathcal{F}$ Clin Microbiol 1984;20:490-3.

36 Brock BV, Selke S, Benedetti J, Douglas JM, Corey L. Frequency of asymptomatic shedding of HSV in women with genital herpes $¥ A M A 1990 ; 263: 418-20$.

37 Langenberg A, Benedetti J, Jenkins J, Ashley RL, Winter C, Corey L. Development of clinically recognizable genital lesions among women previously identified as having "asymptomatic" herpes simplex virus type 2 infection. Ann Intern Med 1989;110:882-7.

38 White WB, Hanna M, Stewart AJ. Proctitis, urinary retention, arthralgias, and meningitis in the absence of primary mucocutaneous lesions. Arch Intern Med 1984;144:826-7.

39 Piot P, Plummer FA. Genital ulcer adenopathy syndrome. In: Holmes $\mathrm{KK}$, Mardh PA, Sparling PF, Wiesner PJ, eds. Sexually Transmitted Diseases, 2nd Edn. New York: McGraw Hill, 1989; 711-6.

40 Brown ZA, Vontver LA, Benedetti J, et al. Effects on infants of a first episode of genital herpes during pregnancy. N Engl f Med 1987;317:1246-51.

41 Whitley RJ. Perinatal herpes simplex virus infections. Rev Med Virol 1991;1:101-10.

42 Arvin AM, Prober CG. Herpes simplex virus infections in pregnancy. Pediatr Infect Dis $\mathcal{f} 1990 ; 9: 765-7$.

43 Prober CG, Corey L, Brown ZA, et al. A consensus on the management of pregnant women with genital 15:1031-8.

44 Prober CG, Sullender WM, Yasukawa LL, Au DS, Yeager AS, Arvin AM. Low risk of herpes simplex virus infections in neonates exposed to the virus at the virus infections in neonates exposed to the virus at the genital herpes simplex virus infections. $N$ Engl $f \mathrm{Med}$ 1987;316:240-4.

45 Brown ZA, Benedetti J, Ashley R, et al. Neonatal herpes simplex virus infection in relation to asymptomatic maternal infection at the time of labor. $N \mathrm{Engl} f \mathrm{Med}$ 1991;324:1247-52.

46 Kulhanjian JA, Soroush V, Au DS, et al. Identification of women at unsuspected risk of primary infection with herpes simplex virus type 2 during pregnancy. $N$ Engl $f$ Med 1992;326:916-20.

47 Hardy DA, Arvin AM, Yasukawa LL, Lewinsohn DM, Hensleigh PA, Prober CG. The successful identification of asymptomatic genital herpes simplex infection at delivery using the polymerase chain reaction. $₹$ Infect Dis 1990;162:1031-5.

48 Arvin AM, Hensleigh PA, Prober CG, et al. Failure of antepartum maternal cultures to predict the infant's risk of exposure to herpes simplex virus at delivery. N Engl f Med 1986;315:796-800.

49 Kimura H, Futamura $M$, Kito $H$, et al. Detection of viral DNA in neonatal herpes simplex virus infections: frequent and prolonged presence in serum and cerebrospinal fluid. $\Im$ Infect Dis 1991;164:289-93.

50 Thomas EE, Scheifele DW, MacLean BS. Herpes simplex type 2 aspetic meningitis in a two-month-old

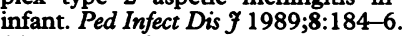

51 Ashley RL. Genital Herpes Infections. Clinics in Laboratory Medicine. In: Judson FN, eds. Sexually Transmitted Diseases Philadelphia: W.B. Saunders Co, 1989:405-20.

52 Prymas LA, Venezia RA, McSharry MM. Enhanced method of herpes simplex virus culture confirmation using the virogen herpes slide test. $₹$ Clin Microbio 1987;25:2004-5.

53 Patel H, Frenkel LD, Greenhalgh M, Howell R, Patel S. Rapid culture confirmation of herpes simplex virus by a monoclonal antibody-based enzyme immunoassay. f Clin Microbiol 1991;29:410-2.

54 Peterson EM, Aarnaes SL, Bryan RN, et al. Typing of herpes simplex virus with synthetic DNA probes. $\mathcal{f}$ Infect Dis 1986;153:757-62.

55 Zheng ZM, Mayo DR, Hsuing GD. Comparison of biological, biochemical, immunological, and immunochemical techniques for typing herpes simplex virus isolates. F Clin Microbiol 1983;17:396-9.

56 Mayo DR. Differentiation of herpes simplex virus types 1 and 2 by sensitivity to (E)-5(2-Bromovinyl)-2' Deoxyuridine. F Clin Microbiol 1982;15:733-6.

57 Nerurkar LS, Miller NR, Namba M, et al. Typing of herpes simplex virus by capture Biotin-Streptavidin enzyme-linked immunosorbent assay and comparison with restriction endonuclease analysis and immunofluorescence method using monoclonal antibodies. $\mathcal{F}$ Clin Microbiol 1987;25:128-32.

58 Swierkosz EM, Arens MQ, Schmidt RR, Armstrong T. Evaluation of two immunofluorescence assays with monoclonal antibodies for typing of herpes simplex virus. $\mathcal{F}$ Clin Microbiol 1985;21:643-4.

59 Sutherland S, Morgan B, Mindel A, Chan WL. Typing and subtyping of herpes simplex isolates by monoclonal fluorescence. $\mathcal{F}$ Med Virol 1986;18:235-45.

60 Peterson E, Schmidt OW, Goldstein LC, et al. Typing of clinical herpes simplex virus isolates with mouse monoclonal antibodies to herpes simplex virus types 1 and 2: comparison with type-specific rabbit antisera and restriction endonuclease

61 Pereira L, Dondero D, Norrild B, Roizman B. Differential immunologic reactivity and processing of glycoproteins $\mathrm{gA}$ and $\mathrm{gB}$ of herpes simplex virus types 
1 and 2 made in vero and Hep-2 cells. Proc Natl Acad Sci USA 1981:78:5202-6.

62 Okazaki K, Chiya S, Ideguchi S, Kimura S. Typing of herpes simplex virus types 1 and 2 by immunoblotting analysis using polyclonal antisera to herpes simple virus glycoproteins. $\mathcal{F}$ Virol Methods 1987;18:169-78.

63 Lipson SM, Salo RJ, Leonardi GP. Evaluation of five monoclonal antibody-based kits or reagents for the identification and culture confirmation of herpes sim plex virus. ₹ Clin Microbiol 1991;29:466-9.

64 Hughes JH, Hamparian VV, Mavromoustakis CT Continuous high-speed rolling versus centrifugation for detection of herpes simplex virus. $\mathfrak{f}$ Clin Microbiol for detection of

65 Luker G, Chow C, Richards DF, Johnson FB. Suitability of infection of cells in suspension for detection of herpes simplex virus. F Clin Microbiol 1991;29:1554-7.

66 Woods GL, Mills RD. Conventional tube cell culture compared with centrifugal inoculation of MRC-5 cells and staining with monoclonal antibodies for detection of herpes simplex virus in clinical specimens. $₹ \mathrm{Clin}$ Microbiol 1988;26:570-2.

67 Gleaves CA, Wilson DJ, Wold AD, Smith TF. Detection and serotyping of herpes simplex virus in MCR-5 cells by use of centrifugation and monoclonal antibodies 16 h postinoculation. $¥$ Clin Microbiol 1985;21:29-32.

68 Espy MJ, Smith TF. Detection of herpes simplex virus in conventional tube cell cultures and in shell vials with a DNA probe kit and monoclonal antibodies. $f$ Clin Microbiol 1988;26:22-4.

69 Barr RJ, et al. Rapid method for tzanck preparations. भAMA 1977;237:1119-21.

70 Solomon AR, Rasmussen JE, Varani J, Pierson CL. The tzanck smear in the diagnosis of cutanequs herpes simplex. $¥ A M A$ 1984;251:633-5.

71 Baker DA, Gonik B, Milch PO, Berkowitz A, Lipson S, Verma U. Clinical Evaluation of a new herpes simplex virus ELISA: a rapid diagnostic test for herpes simplex virus ELISA: a rapid diagnostic test

72 virus. Obst Gynecol 1989;73:322-5. Comparison of two enzyme-linked immunosorbent assays for detection of herpes simplex virus antigen f Clin Microbiol 1991;29:436-8.

73 Verano L, Michalski FJ. Herpes simplex virus antigen direct detection in standard virus transport medium by Du Pont Herpchek enzyme-linked immunosorben assay. F Clin Microbiol 1990;28:2555-8.

74 Corey L., Spear PG. Infections with herpes simplex viruses. $N$ Engl $₹$ Med 1986;314:749-57.

75 Lakeman FD, Koga J, Whitley RJ. Detection of antigen to herpes simplex virus in cerebrospinal fluid from patients with herpes simplex encephalitis. F Infect Dis patients with herpes

76 Fung JC, Shanley J, Tilton RC. Comparison of the detection of herpes simplex virus in direct clinical specimens with herpes simplex virus-specific DNA probes and monoclonal antibodies. $\mathcal{f}$ Clin Microbio 1985;22:748-53.

77 Forghani B, Dupuis KW, Schmidt NJ. Rapid detection of herpes simplex virus specific-DNA in human brain tissue by in situ hybridization. $\mathcal{f}$ Clin Microbiol 1985 22:656-8.

78 Langenberg A, Smith D, Brakel CL, et al. Detection of herpes simplex virus DNA from genital lesions by in situ hybridization. $\mathcal{F}$ Clin Microbiol 1988;26:933-7.

79 Seal LA, Toyama PS, Fleet KM, et al. Comparison of standard culture methods, a shell vial assay, and DNA probe for the detection of herpes simplex virus. I Clin Microbiol 1991;29:650-2.

80 Matsumoto T, Yamada O, Itagaki A, Ishida $S$, Kamahora T, Kurimura T. Rapid DNA diagnosis of herpes simplex virus serotypes. $\mathcal{f}$ Virol Methods 1982;40:119-26.

81 Aurelius E, Johansson B, Skoldenberg B, Staland A Forsgren M. Rapid diagnosis of herpes simplex encephalitis by nested polymerase chain reaction assay of cerebrospinal fluid. Lancet 1991;337:198-2.

82 Pohl-Koppe A, Dahm C, Elgas M, Kuhn JE, Braun RW, Volker ter Meulen. The diagnostic significance of the polymerase chain reaction and isoelectric focusing in polymerase chain reaction and isoelectric focusing in
herpes simplex virus encephalitis. $\mathcal{F}$ Med Virol 1992;36: herpes sim

83 Yamamoto LJ, Tedder DG, Ashley R, Levin MJ. Herpes simplex virus type 1 DNA in cerebrospinal fluid of a patient with Mollaret's meningitis. N Engl $\mathcal{F} \mathrm{Med}$ 1991;23:1082-5.

84 Nahmias AJ, Whitley RJ, Visintine AN, Takei Y, Alford CA. Herpes simplex virus encephalitis: laboratory evaluations and their diagnostic significance. $\mathcal{F}$ Infect $D i$ 1982;145:829-36.

85 Ehrlick GD. Caveats of PCR. Clin Microbiol Newsletter 1991;13:149-51

86 Kwok S, Higuchi R. Avoiding false positives with PCR Nature 1989;339:237-8.

87 Ashley R.L, Corey L. Effect of acyclovir treatment of primary genital herpes on the antibody response to herpes mary genital herpes on the antibody response

88 Bernstein DI, Lovett MA, Bryson YJ. The effects of acyclovir on antibody response to herpes simplex virus in primary genital herpetic infections. $\mathcal{F}$ Infect Dis 1984; primary geni

89 Ashley R, Mack K, Critchlow C, Shurtleff M, Corey L. Differential effect of systemic acyclovir treatment of genital HSV-2 infections on antibody responses to individual HSV-2 proteins. $f$ Med Virol 1988;24: 309-20.

90 Ashley R, Cent A, Maggs V, Nahmias A, Corey L Inability of enzyme immunoassays to discriminate between infections with herpes simplex virus types 1 or 2. Ann Intern Med 1991;115:520-6.

91 Kahlon J, Chatterjee S, Lakeman FD, Lee F, Nahmias AJ, Whitley RJ. Detection of antibodies to herpes simplex virus in the cerebrospinal fluid of patients with herpes simplex encephalitis. $\mathcal{F}$ Infect Dis 1987;155: 38-44.

92 Bergstrom T, Vahlne A, Alestig K, Jeansson S, Forsgren $M$, Lycke E. Primary and recurrent herpes simplex virus type 2 -induced meningitis. $\mathcal{F}$ Infect $D$ is 1990;162: 322-30.

93 Pauls FP, Dowdle WR. A serological study of herpesvirus hominis strains by microneutralization tests. $\mathfrak{f}$ Immunol 1967;98:941-7.

94 Rawls WE, Iwamoto K, Adam E, Melnick JL. Measurement of antibodies to herpesvirus types 1 and 2 in human sera. F Immunol 1970;104:599-606.

95 Nahmias AJ, Josey WE, Naib ZM, Luce CF, Duffey A Antibodies to herpesvirus hominis types 1 and 2 in humans. $¥$ Epidemiol 1970;91:539-46.

96 Kohl S, Adam E, Matson DO, Kaufman RH, Dreesman GR. Kinetics of human antibody responses to primary genital herpes simplex virus infection. Intervirology 1982;18:164-8.

97 Cranage MP, McLean CS, Buckmaster EA, Minson AC Wildy P, Coombs RRA. The use of monoclonal antibodies in (reverse) passive haemagglutination tests for herpes simplex virus antigens and antibodies. $f \mathrm{Med}$ Virol 1983;11:295-306.

98 Plummer G. A review of the identification and titration of antibodies to herpes simplex virus type 1 and type 2 in human sera. Cancer Res 1973;33:1469-76.

99 Ashley R, Militoni J. Use of densitometric analysis for interpreting HSV serologies based on Western Blot. interpreting HSV serologies basec

100 Moore DE, Ashley R, Zarutskie PW, Coombs R, Soules $M R$, Corey L. Transmission of genital herpes by artifcial insemination with a donor experiencing asymptomatic primary HSV-2 infection. $尹 A M A$ 1989;261 3441-3.

101 Coleman RM, Pereira L, Bailey PD, Dondero D, Wickliffe C, Nahmias AJ. Determination of herpes simplex virus type-specific antibodies by enzymelinked immunosorbent assay. F Clin Microbiol 1983; 18:287-91.

102 Svennerholm B, Olofsson S, Jeansson S, Vahlne A Lycke E. Herpes simplex virus type-selective enzymelinked immunosorbent assay with Helix pomatia lectin-purified antigens. $\Im$ Clin Microbiol 1984;19: 235-9.

103 Lee FK, Coleman RM, Pereira L, Bailey PD, Tatsuno $M$, Nahmias AJ. Detection of herpes simplex virus type 2-specific antibody with glycoprotein G. F Clin Microbiol 1985;22:641-4.

104 Lee FK, Pereira L, Griffin C, Reid E, Nahmias A. A novel glycoprotein for detection of herpes simplex 1986;14:111-8.

105 Sullender WM, Yasukawa LL, Schwartz M, et al. Typespecific antibodies to herpes simplex virus type 2 (HSV-2) glycoprotein G in pregnant women, infants exposed to maternal HSV-2 infection at delivery, and infants with neonatal herpes. $\mathcal{F}$ Infect Dis 1988;157: infants $164-71$.

106 Ho DWT, Field PR, Sjogren-Jansson E, Jeansson S Cunningham AL. Indirect ELISA for the detection of HSV-2 specific IgG and IgM antibodies with glycoprotein G (gG02). 于 Virol Methods 1992;36:249-64.

107 Parks DL, Smith CM, Rose JM, Brandis J, Coates SR. Seroreactive recombinant herpes simplex virus type 2-specific glycoprotein G. F Clin Microbiol 1991;29: 778-81.

108 Sanchez-Martinez D, Schmid DS, Whittington W, et al. Evaluation of a test based on baculovirus-expressed glycoprotein $G$ for detection of herpes simplex virus glycoprotein $G$ for detection of herpes simplex virus

109 Ashley R and Koelle DM. Immune Responses to Genital Herpes Infection. Advances in Host Defense Mechanisms. In: Quinn TC, ed. Sexually Transmitted Diseases New York: Raven Press, 1992; 201-238.

110 Safrin S, Arvin AM, Mills J, Ashley R. Comparison of Western blot assay and a glycoprotein-G enzym immunoassay for detection of serum antibodies to HSV-2 in patients with acquired immunodeficiency syndrome. f Clin Microbiol 1992;30:1312-14.

111 Ashley R, Corey L. Association of herpes simplex virus polypeptide specific antibodies and the natural history of genital herpes infections. In: Herpe
Alan R. Liss, Inc., 1984;21:37-54.

112 Ashley RL, Militoni J, Lee F, Nahmias A, Corey L Comparison of Western blot (immunoblot) and glycoprotein G-specific immunodot enzyme assay for protein G-specific immunodot enzyme assay for 2 in human sera. $₹$ Clin Microbiol 1988;26:662-7.

113 Dalessio J, Ashley R. A highly sensitive enhanced chemiluminescence immunodetection method for herpes simplex virus-2 Western blot. f Clin Microbiol 1992 30:1005-7. 